Open Access

\title{
Using e-Assessment to enhance student learning and evidence learning outcomes
}

Geoffrey Crisp ${ }^{1 *}$, Lourdes Guàrdia ${ }^{2}$ and Mathew Hillier ${ }^{3}$

\author{
* Correspondence: \\ g.crisp@unsw.edu.au \\ ${ }^{1}$ Office Pro-Vice Chancellor \\ (Education), University of New \\ South Wales, Sydney 1426, Australia \\ Full list of author information is \\ available at the end of the article
}

Assessment is an essential component in the learning and teaching environment and should promote learning as well as measure or certify outcomes (Clements \& Cord 2013). There have been significant changes in the approaches to teaching and learning in higher education with the advent of MOOCs, flipped classroom approaches, the introduction of informal learning spaces, the gamification of learning and the expectation of more flexible modes of delivery. We have not seen as much activity in the assessment area to align these changes in teaching with how we use assessment (Guàrdia, in press).

Technology has promoted changes in our understanding of how curricula might be designed and delivered but new approaches to assessment are still needed. Usercentred approaches to assessment involving authentic assessment tasks are now being discussed more often (Mora, Sancho-Bru, Iserte, \& Sánchez, 2012; Mueller, 2014).

This special edition captures some of the recent investigations in e-assessment that move us beyond the traditional selected response formats of multiple-choice tests, short answer, fill-in-the-blanks, true-false, and matching. Higher-level cognitive and affective skills cannot readily be assessed using traditional selected response formats and more authentic e-assessments are being proposed (Kuh, Jankowski, Ikenberry, \& Kinzie 2014).

The paper by James explores the outcomes of a trial of an online final examination in a first year distance education psychology course invigilated via webcam. The study argued for the need to deliver better high stakes assessment to distance education students in a way that aimed to enhance convenience for students while maintaining the validity of the testing process. In this study about one quarter of students in the trial were initially enthusiastic however it was not until they had completed a practice online invigilated exam that the majority of these elected to decline the online approach to their final examination. The paper summarises the process and the concerns of students with this type of assessment. The findings demonstrated the importance of complex contextual matters such as technology compatibility, network reliability, clear communication, logistics and support available for students when implementing new computerised approaches to high stakes assessment.

The paper by Gil-Jaurena and Kucina outlines the TALOE (Time to Assess Learning Outcomes in E-learning) project that developed a web tool for teachers so that they could make informed choices on how to assess online courses. A 
model based on a revised Bloom's taxonomy is aligned with the learning objectives and the tool automatically recommends appropriate assessment methods. The paper reports on the development of the tool and the results of its use; various stakeholders have provided feedback about the efficacy of the tool, as well as the quality of the recommendations it provides. The paper provides a useful summary of the limitations and strengths of the tool so other teachers can make an informed judgement about the use of this approach to enhancing assessment.

The paper by Tarricone and Newhouse provides an interesting case for the use of comparative judgement delivered through online technologies as a viable, valid and reliable alternative to traditional analytical marking. The authors describe how large scale comparative judgement and the use of many judges can be facilitated through the use of supporting technologies. The disciplines investigated in this work include performance areas such as visual and performing arts and demonstrate how technology can assist assessors in using appropriate assessment methods in performance to ensure valid and reliable judgements of students' work.

The paper by Ion, Barrera and Tomas describes the analysis of feedback provided to students in peer-assessment of group work projects and the students' perception of the potential of peer-assessment to improve learning. The paper outlines the process for an effective instructional design approach in order to achieve enhancements in deep learning, and a more active role for students in planning their own development. A semantic analysis of the type of feedback was undertaken in addition to a survey of teachers and students about their experience in this process. The results demonstrate that the majority of feedback offered by students was related to task development, followed by feedback regarding the motivational aspects of the process and finally the structural and formal aspects of the writing. Both teachers and students indicated that the feedback received assisted students in their future learning.

This paper by Romeu, Romero and Guitert investigates the more active role of students in the assessment design phase so that students are not simply the passive recipients of an assessment task but are genuinely involved in its planning and construction. The paper explores the concept of a $360^{\circ}$ continuous e-assessment approach whereby students are involved in all stages of the assessment process. Self-assessment and peer-assessment are key components of the process as well as reflections on teamwork. Students reported a high level of satisfaction with approach to including them as more active partners in assessment.

The papers in this special edition encourage us to understand in greater detail how technology can be used to promote authentic and meaningful assessments and not just making assessments more efficient, and how to deploy e-assessment alongside other strategies. More open-ended tasks and detailed feedback to students are two areas of continuing need in e-assessment. Assessment analytics is emerging from the current move to promote learning analytics (Knight, Buckingham Shum, Littleton, 2014). As we move to change our assessments so they replicate or integrate authentic contexts requiring complex thinking, problem-solving and collaboration strategies we will facilitate the development and reporting of more sophisticated learning outcomes. 
Author details

${ }^{1}$ Office Pro-Vice Chancellor (Education), University of New South Wales, Sydney 1426, Australia. ${ }^{2}$ eLearn Center, Universitat Oberta de Catalunya, Barcelona 08018, Spain. ${ }^{3}$ Office of the Vice Provost Learning and Teaching, Monash University, Melbourne 3145, Australia.

Received: 15 March 2016 Accepted: 15 March 2016

Published online: 30 April 2016

\section{References}

Clements, M. D., \& Cord, B. A. (2013). Assessment guiding learning: developing graduate qualities in an experiential learning programme. Assessment and Evaluation in Higher Education, 38(1), 114-124.

Guàrdia, L., Crisp, G., \& Alsina, I. Trends and challenges of e-assessment to enhance student learning in Higher Education. In Cano, E., \& Ion, G. (Eds.), Innovative Practices for Higher Education Assessment and Measurement (pp. XX-Xx). Hershey PA, (USA): IGI Global. (in press)

Knight, S., Buckingham Shum, S., \& Littleton, K. (2014). Epistemology, assessment and pedagogy: where learning meets analytics in the middle space. Journal of Learning Analytics, 1(2), 23-47.

Kuh, G. D., Jankowski, N., Ikenberry, S. O., \& Kinzie, J. (2014). Knowing What Students Know and Can Do: The Current State of Student Learning Outcomes Assessment in US Colleges and Universities. Urbana: University of Illinois and Indiana University, National Institute for Learning Outcomes Assessment (NILOA).

Mora, M. C., Sancho-Bru, J. L., Iserte, J. L., \& Sánchez, F. T. (2012). An e-assessment approach for evaluation in engineering overcrowded groups. Computers and Education, 59, 732-740.

Mueller, J. (2014). Authentic assessment toolbox. North Central College, Naperville. Retrieved from: http://jfmueller. faculty.noctrl.edu/toolbox/whydoit.htm

Submit your manuscript to a SpringerOpen ${ }^{\circ}$ journal and benefit from:

- Convenient online submission

Rigorous peer review

- Immediate publication on acceptance

- Open access: articles freely available online

- High visibility within the field

- Retaining the copyright to your article 